\title{
ANALISIS PENGARUH BELANJA PEMERINTAH, TENAGA KERJA, DAN PENDAPATAN ASLI DAERAH TERHADAP PERTUMBUHAN EKONOMI REGIONAL PROVINSI JAWA TIMUR TAHUN 2010-2015
}

\author{
Avicenna S Hidayat ${ }^{(1)}$ \\ Frederic Winston Nalle ${ }^{(2)}$ \\ Fakultas Ekonomi dan Bisnis - Universitas Wisnuwardhana Malang ${ }^{(1)}$ \\ Fakultas Ekonomi dan Bisnis - Universitas Timor ${ }^{(2)}$ \\ Email: masterphizz@gmail.com
}

\begin{abstract}
Regional economic growth is expressed in the Gross Domestic Regional Product is a good indicator in analyzing the economic conditions of a region. East Java is a province with high regional economic growth. This is supported by adequate government spending, labor, and local revenue. In terms of government expenditure that always experienced increase, indicating more activities financed by the government budget so that the expected multiplier effect is also greater. On the other side of the labor force, East Java has great potential, 19, 36 million people by 2015. Finally, in terms of Original Local Government Revenue, in 2015 the percentage of realization of Original Local Government Revenue East Java is even able to exceed the percentage of realization of state revenues derived from taxes. This study aims to determine the effect of government spending, labor, and Original Local Government Revenue on regional economic growth in 38 districts / cities in the Province of East Java period 2010-2015. Using panel data analysis, it was found that government spending, labor, and Original Local Government Revenue variables were positively and significantly influenced regional economic growth.
\end{abstract}

Keywords : Government Expenditure, Labor, Original Local Government Revenue, regional economic growth

\begin{abstract}
ABSTRAK
Pertumbuhan ekonomi regional yang dinyatakan dalam PDRB merupakan indikator yang baik dalam menganalisis kondisi perekonomian suatu wilayah. Jawa Timur merupakan provinsi dengan capaian pertumbuhan ekonomi regional yang tinggi. Hal ini ditunjang oleh faktor belanja pemerintah, tenaga kerja, dan Pendapatan Asli Daerah yang memadai. Dari segi belanja pemerintah yang selalu engalami kenaikan, mengindikasikan semakin banyak kegiatan yang dibiayai oleh anggaran pemerintah sehingga multiplier effect yang diharapkan juga semakin besar. Di sisi lain dari segi tenaga kerja, Jawa Timur memiliki potensi yang besar, 19, 36 juta orang pada 2015. Terakhir, dari sisi PAD, pada tahun 2015 persentase realisasi PAD Jawa Timur bahkan mampu melampaui persentase realisasi pendapatan negara yang bersumber dari pajak. Penelitian ini bertujuan untuk mengetahui pengaruh belanja pemerintah, tenaga kerja, dan PAD terhadap pertumbuhan ekonomi regional di 38 kabupaten/kota di Provinsi Jawa Timur periode 2010-2015. Dengan menggunakan analisis data panel, ditemukan bahwa variabel belanja pemerintah, tenaga kerja, dan PAD berpengaruh secara positif dan signifikan terhadap pertumbuhan ekonomi regional.
\end{abstract}

Kata kunci: belanja pemerintah, tenaga kerja, PAD, pertumbuhan ekonomi regional

\section{PENDAHULUAN}

Salah satu tujuan yang pasti dari proses pembangunan nasional adalah pertumbuhan ekonomi tinggi dan merata, baik dalam jangka pendek maupun jangka panjang. Pembangunan ekonomi regional 
Analisis Pengaruh Belanja Pemerintah, Tenaga Kerja dan.......( Hidayat, Nalle)

merupakan bagian integral dari pembangunan nasional, sehingga tujuan pertumbuhan ekonomi nasional tinggi hanya akan tercapai jika didukung oleh pertumbuhan ekonomi regional yang memadai. Secara definisi, pembangunan ekonomi meliputi usaha-usaha meningkatkan taraf hidup suatu bangsa yang seringkali diukur dengan tinggi rendahnya pendapatan riil perkapita. Disamping itu, pembangunan ekonomi hendaknya dapat meningkatkan produktivitas, atau dengan kata lain dapat memberikan kemampuan kepada manusia bagaimana mengelola sumber daya alam disekitarnya (Suparmoko, 2002).

Jawa Timur merupakan provinsi yang mempunyai record baik dalam hal pertumbuhan ekonomi regional. Pertumbuhan ekonomi Jawa Timur, yang diproksikan ke dalam PDRB, menempati urutan ke-dua tertinggi di Pulau Jawa setelah Provinsi DKI Jakarta. Selain itu, PDRB Jawa Timur juga tercatat selalu mengalami kenaikan, setidaknya dalam kurun waktu lima tahun terakhir. Kondisi tersebut dapat dilihat pada tabel berikut ini:

Tabel 1. PDRB Atas Dasar Harga Konstan 2010 Provinsi di Pulau Jawa Periode 2011-2015

\begin{tabular}{cccccc}
\hline \multirow{2}{*}{ Provinsi } & \multicolumn{5}{c}{ Produk Domestik Regional Bruto (Milyar Rupiah) } \\
\cline { 2 - 6 } & $\mathbf{2 0 1 1}$ & $\mathbf{2 0 1 2}$ & $\mathbf{2 0 1 3}$ & $\mathbf{2 0 1 4}$ & $\mathbf{2 0 1 5}$ \\
\hline DKI Jakarta & $1.147 .558,23$ & $1.222 .527,92$ & $1.296 .694,57$ & $1.373 .389,55$ & $1.454 .102,11$ \\
\hline Jawa Timur & $1.054 .401,77$ & $1.124 .464,64$ & $1.192 .789,80$ & $1.262 .697,06$ & $1.331 .418,24$ \\
\hline Jawa Barat & $965.622,06$ & $1.028 .409,74$ & $1.093 .543,55$ & $1.149 .231,43$ & $1.207 .001,49$ \\
\hline Jawa Tengah & $656.268,13$ & $691.343,12$ & $726.655,12$ & $764.992,65$ & $806.609,02$ \\
\hline Banten & $290.545,84$ & $310.385,59$ & 331.099 .11 & $349.205,70$ & $367.959,22$ \\
\hline DIY & $68.049,87$ & $71.702,45$ & $75.627,45$ & $79.532,28$ & $83.461,57$ \\
\hline
\end{tabular}

Sumber: BPS (2017)

Dengan capaian pertumbuhan ekonomi yang tinggi, pemerintah Jawa Timur memiliki kewajiban untuk memastikan bahwa pertumbuhan ekonomi tersebut menghasilkan kemakmuran dan kesejahteraan bagi masyarakat. Kesejahteraan masyarakat dapat dicapai apabila kegiatan ekonomi terus bertumbuh. Salah satu cara untuk memicu kegiatan ekonomi adalah melalui belanja pemerintah. Belanja pemerintah terdiri dari belanja langsung (belanja yang dikeluarkan atau dianggarkan terkait secara langsung dengan pelaksanaan 
program dan dan kegiatan) dan belanja tidak langsung (belanja yang tidak terkait tidak langsung dengan kegiatan program pemerintah). Belanja langsung terbagi ke dalam tiga kelompok, yakni belanja pegawai, belanja barang dan jasa, serta belanja modal.

Belanja pemerintah berkaitan erat dengan pertumbuhan ekonomi karena belanja pemerintah merupakan komponen penyusun Produk Domestik Bruto (atau PDRB dalam skala regional), bersama dengan konsumsi masyarakat, investasi, dan net ekspor. Pemikiran ini digagas oleh kaum ekonom Keynesian dimana mereka mendasari pemikiran bahwa variabel pemerintah (khususnya anggaran) dianggap sebagai salah satu variabel penggerak pertumbuhan ekonomi di suatu negara. Anggaran dari pemerintah diharapkan akan menciptakan multiplier effect pada sektor-sektor ekonomi lainnya. Multiplier effect pengeluaran pemerintah ini akan semakin besar jika asumsi bahwa belanja pemerintah digunakan untuk kegiatan produktif dapat terpenuhi (Kemenkeu, 2014). Data realisasi belanja pemerintah daerah Jawa Timur yang bersumber dari Badan Pusat Statistik menunjukkan bahwa terjadi peningkatan belanja pada periode 2011-2014. Tercatat berturut-turut belanja pemerintah Jawa Timur pada 2011 sebesar 43.214.949 juta rupiah; tahun 2012 sebesar 50.824.751 juta rupiah; tahun 2013 sebesar 57.551.593 juta rupiah; dan pada tahun 2014 sebesar 61.057.562 juta rupiah. Hal ini mengindikasikan bahwa dari tahun ke tahun terdapat semakin banyak kegiatan yang dibiayai oleh pemerintah dan manfaat kesejahteraan yang diharapkan dari kegiatan-kegiatan tersebut juga semakin tinggi.

Selain faktor belanja pemerintah, Jawa Timur memiliki potensi sumber daya manusia yang melimpah. Barang dan jasa yang dihasilkan di suatu wilayah yang pada akhirnya dihitung ke dalam PRDB tidak terlepas dari sumber daya manusia yang tersedia. Perekonomian yang bergerak cepat pun pada akhirnya berpengaruh pada penyerapan tenaga kerja. Penyerapan tenaga kerja yang tinggi akan menekan tingkat pengangguran dan dalam jangka panjang meningkatkan kesejahteraan. Maka 
Analisis Pengaruh Belanja Pemerintah, Tenaga Kerja dan.......( Hidayat, Nalle)

kebijakan mengenai perluasan kesempatan kerja merupakan hal penting di suatu daerah, karena dapat menjadi tolok ukur bagi keberhasilan pembangunan ekonomi itu sendiri. Data mengenai tenaga kerja Jawa Timur yang bersumber dari Badan Pusat Statistik menyatakan bahwa pada tahun 2015 terdapat 19.367 .777 orang tenaga kerja yang terbagi ke dalam sektorsektor berikut:

Tabel 2.Penduduk Berumur 15 Tahun ke Atas yang Bekerja Menurut Lapangan Pekerjaan Utama di Jawa Timur Tahun 2015

\begin{tabular}{lc}
\hline \multicolumn{1}{c}{ Lapangan Pekerjaan Utama } & $\begin{array}{c}\text { Jumlah Tenaga } \\
\text { Kerja }\end{array}$ \\
\hline $\begin{array}{l}\text { Pertanian, Perkebunan, Kehutanan, Perburuan, } \\
\text { dan Perikanan }\end{array}$ & 7.083 .252 \\
\hline Pertambangan dan Penggalian & 125.813 \\
\hline Industri & 2.699 .676 \\
\hline Listrik, Gas, dan Air Minum & 29.217 \\
\hline Konstruksi & 1.510 .085 \\
\hline $\begin{array}{l}\text { Perdagangan, Rumah Makan, dan Jasa } \\
\text { Akomodasi }\end{array}$ & 4.121 .312 \\
\hline Transportasi, Pergudangan, dan Komunikasi & 636.150 \\
\hline $\begin{array}{l}\text { Lembaga Keuangan, Real Estate, Usaha } \\
\text { Persewaan, dan Jasa Perusahaan }\end{array}$ & 410.912 \\
\hline Jasa Kemasyarakatan, Sosial, dan Perorangan & 2.751 .360 \\
\hline \multicolumn{2}{c}{ TOTAL } \\
\hline
\end{tabular}

Sumber: BPS (2017)

Pendapatan asli daerah (PAD) merupakan komponen dari pendapatan daerah yang dipungut berdasarkan peraturan daerah yang sesuai dengan perundang-undangan yang berlaku. Sektor pendapatan daerah merupakan sektor yang memiliki peranan penting, dikarenakan melalui sektor ini dapat dilihat sampai sejauh mana suatu daerah dapat membiayai kegiatan pemerintahan dan pembangunan daerahnya secara mandiri. Pada tahun 2015, target PAD Jawa Timur adalah sebesar 12,34 triliun rupiah, sedangkan realisasinya mampu melebihi target, yakni sebesar 12,56 triliun rupiah, yang di antaranya disumbang oleh pajak kendaraan bermotor (PKB) sebesar 4,911 triliun rupiah; pajak bahan bakar kendaraan bermotor (PBBKB) sebesar 2,201 triliun rupiah; bea balik nama kendaraan bermotor (BBNKB) sebesar 3,534 triliun rupiah; pajak rokok 1,819 triliun rupiah; retribusi jasa usaha terealisasi 2,849 miliar 
rupiah, dan penerimaan lain-lain dari parkir berlangganan terealisasi 20,893 miliar rupiah. Capaian realisasi PAD yang bersumber dari pajak Provinsi Jawa Timur bahkan melampaui realisasi pendapatan asli negara yang dikumpulkan pemerintah pusat, yaitu 84,5 persen dari target yang ditetapkan. Semakin tinggi proporsi PAD terhadap total pendapatan daerah, maka suatu daerah dapat dikatakan lebih mandiri. Berdasarkan serangkaian latar belakang di atas mengenai pentingnya variabelvariabel di atas bagi PDRB, .maka dilakukan studi ini dengan tujuan mengetahui pengaruh belanja pemerintah, tenaga kerja, dan PAD terhadap pertumbuhan ekonomi regional di Provinsi Jawa Timur.

\section{Pertumbuhan dan Pembangunan}

\section{Ekonomi}

Prioritas utama pemerintah daerah adalah mencapai pertumbuhan ekonomi tinggi dan menciptakan kesejahteraan bagi masyarakatnya. Dalam era pelaksanaan otonomi daerah, kemajuan ekonomi daerah tidak lagi bergantung pada pemerintah pusat, sebab pemerintah daerah berwenang mengurus, mengelola, dan mengembangkan potensi daerah masing-masing. Di tingkat daerah, pertumbuhan ekonomi terproksi dalam variabel Produk Regional Domestik Bruto (PDRB), yang merupakan total atas nilai keseluruhan barang dan jasa yang dihasilkan dari seluruh kegiatan di suatu daerah. Baik PDRB atas dasar harga berlaku maupun atas harga konstan, samasama merupakan jumlah nilai tambah barang dan jasa akhir yang dihasilkan oleh seluruh unit usaha dalam suatu wilayah regional tertentu. Bedanya, PDRB atas dasar harga berlaku dapat digunakan untuk melihat pergeseran dan struktur ekonomi karena dihitung menggunakan harga yang berlaku setiap tahunnya, sedangkan PDRB harga konstan digunakan untuk mengetahui pertumbuhan ekonomi dari tahun ke tahun karena menggunakan acuan satu tahun tertentu sebagai tahun dasar.

Proses pembangunan dapat dimaknai sebagai suatu proses merubah sesuatu menjadi lebih baik. Pembangunan ekonomi menurut Todaro dan Smith (2006) adalah suatu proses kenaikan pendapatan total dan pendapatan perkapita dengan memperhitungkan adanya pertambahan penduduk dan disertai 
dengan perubahan fundamental dalam struktur ekonomi suatu negara dan pemerataan pendapatan bagi penduduk suatu negara.

$$
\text { Selanjutnya pembangunan }
$$

ekonomi diartikan sebagai suatu proses yang menyebabkan pendapatan perkapita penduduk meningkat dalam jangka panjang. Terdapat tiga elemen penting yang berkaitan dengan pembangunan ekonomi, yaitu:

a. Pembangunan sebagai suatu proses.

Pembangunan sebagai suatu proses, artinya bahwa pembangunan merupakan suatu tahap yang harus dijalani oleh setiap masyarakat atau bangsa. Setiap bangsa harus menjalani tahap-tahap perkembangan untuk menuju kondisi yang adil, makmur, dan sejahtera.

a. Pembangunan sebagai suatu usaha untuk meningkatkan pendapatan perkapita.

Sebagai suatu usaha, pembangunan merupakan tindakan aktif yang harus dilakukan oleh suatu negara dalam rangka meningkatkan pendapatan perkapita. Dengan demikian, sangat dibutuhkan peran serta masyarakat, pemerintah, dan semua elemen untuk berpartisipasi aktif dalam proses pembangunan. Hal ini dilakukan karena kenaikan pendapatan perkapita mencerminkan perbaikan dalam kesejahteraan masyarakat.

b. Peningkatan pendapatan perkapita harus berlangsung dalam jangka panjang.

Suatu perekonomian dapat dinyatakan dalam keadaan berkembang apabila pendapatan perkapita dalam jangka panjang cenderung meningkat. Akan tetapi, hal ini bukan berarti bahwa pendapatan perkapita harus mengalami kenaikan terus-menerus.

\section{Belanja Pemerintah dalam}

\section{Pertumbuhan Ekonomi}

Mankiw (2006) menyebutkan bahwa pendapatan total perekonomian dalam jangka pendek sangat ditentukan oleh keinginan rumah tangga, perusahaan dan pemerintah untuk membelanjakan pendapatannya.. Kenaikan pengeluaran yang direncanakan akan menyebabkan peningkatan permintaan agregat. Permintaan agregat akan mendorong produksi barang dan jasa yang akan menyebabkan pendapatan juga akan meningkat

Pengeluaran Pemerintah menerut 
Analisis Pengaruh Belanja Pemerintah, Tenaga Kerja dan.......( Hidayat, Nalle)

Sukirno (1994) adalah bagian dari kebijakan fiskal, yaitu suatu tindakan pemerintah untuk mengatur jalannya perekonomian dengan cara menentukan besarnya penerimaan dan pengeluaran pemerintah setiap tahunnya, yang tercermin dalam dokumen Anggaran Pendapatan Belanja Negara (APBN) untuk nasional dan Anggaran Pendapatan Belanja Daerah (APBD) untuk daerah atau regional. Tujuan dari kebijakan fiskal ini adalah dalam rangka menstabilkan harga, tingkat output, maupun kesempatan kerja dan memacu atau mendorong pertumbuhan ekonomi.

Bahwa peranan atau campur tangan pemerintah masih sangat diperlukan yaitu apabila perekonomian sepenuhnya diatur olah kegiatan di pasar bebas, bukan saja perekonomian tidak selalu mencapai tingkat kesemptan kerja penuh tetapi juga kestabilan kegiatan ekonomi tidak dapat diwujudkan. Akan tetapi fluktuasi kegiatan ekonomi yang lebar dari satu periode ke periode lainnya dan ini akan menimbulkan implikasi yang serius kepada kesempatan kerja dan pengangguran dan tingkat harga.

\section{Tenaga Kerja dalam}

\section{Pertumbuhan Ekonomi}

Menurut Todaro (2000), pertumbuhan penduduk dan pertumbuhan Angkatan Kerja (AK) secara tradisional dianggap sebagai salah satu faktor positif yang memacu pertumbuhan ekonomi. Jumlah tenaga kerja yang lebih besar berarti akan menambah tingkat produksi, sedangkan pertumbuhan penduduk yang lebih besar berarti ukuran pasar domestiknya lebih besar. Meski demikian hal tersebut masih dipertanyakan apakan benar laju pertumbhan yang cepat benar-benar akan memberikan dampak positif atau negatif dari pembangunan ekonominya.

Selanjutnya dikatakan bahwa apabila jumlah tenaga kerja ditambah terus menerus sedangkan faktor produksi lain dipertahankan konstan, maka pada awalnya akan menunjukkan peningkatan produktivitas namun pada suatu tingkat akan memperlihatkan penurunan produktivitas serta setelah mencapai tingkat keluaran maksimal setiap penambahan tenaga kerja akan mengurangi pengeluaran. Jumlah 
angkatan kerja yang bekerja merupakan gambaran kondisi dari lapangan kerja yang tersedia. Semakin bertambah besar lapangan kerja yang tersedia, maka akan menyebabkan semakin meningkatnya total produksi di suatu daerah (Kuncoro, 2004).

Pendapatan Asli Daerah dalam

\section{Pertumbuhan Ekonomi}

Menurut Mardiasmo (2002), pendapatan asli daerah adalah penerimaan yang diperoleh dari sektor pajak daerah, retribusi daerah, hasil perusahaan milik daerah, hasil pengelolaan kekayaan daerah yang dipisahkan, dan lain-lain. Jadi pengertian pendapatan asli daerah dapat dikatakan sebagai pendapatan rutin dari usaha-usaha pemerintah daerah dalam memanfataatkan potensi-potensi dari sumber-sumber keuangan untuk membiayai tugastugas dan tanggung jawabnya. Menurut pasal 6 Undang-Undang No. 32 tahun 2004 pendapatan asli daerah berasal dari : 1) Hasil pajak daerah; 2) Hasil retribusi daerah; 3) Hasil perusahaan milik daerah dan hasil pengelolaan kekayaan daerah yang dipisahkan; 4) Penerimaan dari dinas dan lain-lain pendapatan daerah yang sah, yang dijabarkan sebagai berikut: a. Pajak Daerah

Pajak merupakan iuran yang dapat dipaksakan kepada wajib pajak oleh pemerintah dengan balas jasa yang tidak langsung dapat ditunjuk. Pada pokoknya pajak memliki dua peranan utama yaitu sebagai sumber penerimaan negara (fungsi budget) dan sebagai alat untuk mengatur (fungsi regulator) (Suparmoko, 2002). Mardiasmo (1997) mendefinisikan pajak daerah adalah pajak yang dipungut daerah berdasarkan peraturan pajak yang ditetapkan oleh daerah untuk kepentingan pembiayaan rumah tangga daerah tersebut.

b. Retribusi Daerah

Retribusi daerah adalah pungutan yang dilakukan oleh pemerintah pusat karena seseorang atau badan hukum menggunakan jasa dan barang pemerintah yang langsung dapat ditunjuk (Sutrisno, 1984). Peraturan pemerintah No. 66 tahun 2002 tentang retribusi daerah pasal satu menyebutkan bahwa retribusi adalah pungutan daerah sebagai pembayaran atas jasa atau pemberian ijin tertentu yang khusus disediakan oleh pemerintah daerah dengan menganut prinsip komersial karena pada dasarnya dapat pula disediakan oleh 
Analisis Pengaruh Belanja Pemerintah, Tenaga Kerja dan.......( Hidayat, Nalle)

sektor swasta. Menurut UndangUndang No. 34 tahun 2000 tentang retribusi daerah yang selanjutnya disebut retribusi yaitu pungutan daerah sebagai pembeyaran atas jasa atau pemberian ijin tertentu yang khusus disediakan dan atau diberikan oleh pemerintah daerah untuk kepentingan pribadi atau badan.

Pada dasarnya retribusi adalah pajak, tetapi merupakan jenis pajak khusus karena ciri-ciri dan atau syarat-syarat tertentu masih dapat dipenuhi (Sutrisno, 1984). Syaratsyarat tertentu antara lain: berdasarkan Undang-Undang atau peraturan yang sederajat harus disetor ke kas negara atau daerah dan tidak dapat dipaksakan. Batasan pengertian retribusi ini sendiri merupakan pungutan yang dilakukan pmerintah karena seseorang atau badan hukum menggunakan barang dan jasa pemerinta yang langsung dapat ditunjuk.

\section{c. Bagian Laba Perusahaan Daerah}

Perusahaan daerah merupakan salah satu komponen yang diharapkan dalam memberikan kontribusinya bagi pendapatan daerah, tapi sifat utama dari perusahaan daerah bukanlah berorientasi pada keuntungan semata, akan tetapi justru dalam memberikan jasa dan menyelenggarakan kemanfaatan umum, atau dengan perkataan lain perusahaan daerah menjalankan fungsi ganda yang harus terjamin keseimbangannya yaitu fungsi ekonomi (Kaho, 1998). Karena berbentuk perusahaan maka prinsip pengelolaannya berdasarkan atas asasasas ekonomi perushaan. Dengan demikian perushaan harus mencari keuntungan dan selanjutnya sebagian dari keuntungan tersebut diserahkan ke kas daerah. Fungsi pokok dari perushaan daerah adalah : (1) Sebagai dinamisator perekonomian daerah, yang berarti perusahaan daerah harus mampu memberikan rangsangan bagi berkembangnya perekonomian daerah; (2) Sebagai penghasil pendapatan daerah yang berarti harus mampu memberikan manfaat ekonomis sehingga terjadi keuntungan yang dapat diserahkan ke kas daerah.

Berdasarkan uraian diatas, maka perusahaan daerah merupakan salah satu komponen yang diharapkan mampu memberikan kontribusinya bagi pendapatan daerah.

d. Penerimaan dan Pendapatan LainLain yang Sah

Penerimaan lain-lain yang sah 
Analisis Pengaruh Belanja Pemerintah, Tenaga Kerja dan.......( Hidayat, Nalle)

merupakan penerimaan pemerintah daerah diluar penerimaan dinas, pajak, retribusi dan bagian laba perusahaan daerah. Penerimaan ini antara lain berasal dari sewa rumah dinas milik daerah, hasil penjualan barang-barang (bekas) milik daerah, penerimaan sewa kios milik daerah dan penerimaan uang langganan majalah daerah (Hirawan, 1987).

Semakin besar potensi PAD yang dapat digali oleh dinas pendapatan suatu daerah maka optimalisasi penerimaan dapat dilakukan, namun optimalisasi dalam pemungutan PAD hendaknya didukung dengan peningkatan kualitas layanan publik. Eksploitasi PAD yang berlebihan justru akan semakin membebani masyarakat, menjadi disinsentif bagi daerah dan mengancam perekonomian secara makro (Mardiasmo, 2002) Namun si sisi lain kontribusi PAD terhadap total penerimaan daerah merupakan indikator bagi kemandirian suatu daerah. Semakin besar proporsinya, maka pertumbuhan ekonomi regional dapat dicapai secara mandiri.

\section{METODE PENELITIAN}

Data-data dalam penelitian ini diuji menggunakan metode regresi data panel yang menggabungkan data cross section dan time series. Dalam regresi data panel terdapat tiga teknik yang dapat digunakan dalam mengestimasi model regresi, yakni Common Effect (CEM), Fixed Effect (FEM), dan Random Effect (REM). Untuk menentukan model yang tepat dalam analisis data panel, digunakan Chow test dan Hausman test dengan kriteria sebagai berikut:

a. Uji Chow (Chow Test)

Uji ini digunakan menentukan pilihan antara metode CEM atau FEM, dengan menggunakan hipotesis:

H0: Metode yang dipilih Common Effect Model (CEM)

H1: Metode yang dipilih Fixed Effect Model (FEM)

b. Uji Hausman (Hausman Test)

Uji ini digunakan menentukan pilihan antara metode REM atau FEM, dengan menggunakan hipotesis:

H0: Metode yang dipilih Random Effect Model (REM)

H1: Metode yang dipilih Fixed Effect Model (FEM)

Berikutnya, dalam menganalisa pengaruh belanja pemerintah, tenaga 
kerja, dan Pendapatan Asli Daerah

(PAD) terhadap pertumbuhan

ekonomi regional Provinsi Jawa

Timur, digunakan struktur model berikut:

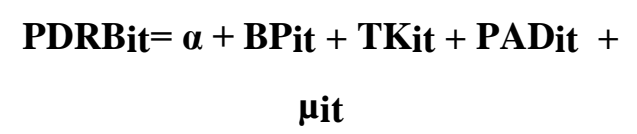

Dimana,

PDRB : Produk Domestik Regional

Bruto (proksi pertumbuhan

ekonomi kabupaten/kota)

BP : Belanja pemerintah

kabupaten/kota

TK : Jumlah tenaga kerja dalam

kabupaten/kota

PAD : Konsumsi pemerintah

(pengeluaran rutin)

kabupaten/kota

$\boldsymbol{\mu} \quad$ : error term

Terakhir, dilakukan pengujian statistik yang meliputi Uji Koefisien Determinasi $\left(\mathrm{R}^{2}\right)$, Uji Signifikansi

Simultan (Uji F), dan Uji Signifikansi Parsial (Uji t).

\section{Definisi Operasional}

PDRB merupakan nilai produksi netto dari barang dan jasa yang dihasilkan daerah dalam jangka waktu tertentu. Data diperoleh dari BPS Provinsi Jawa Timur dalam satuan Rupiah.
BP merupakan belanja yang dilakukan pemerintah daerah dalam satuan Rupiah, meliputi belanja modal yang manfaatnya melebihi satu tahun anggaran, seluruh barang dan jasa yang dibeli oleh pemerintah untuk kegiatan pelayanan masyarakat, pembayaran balas jasa pegawai, penyusutan dan dikurangi penjualan untuk barang dan jasa, dan tidak termasuk pengeluaran pemerintah untuk transfer payment.

TK merupakan penduduk dalam usia kerja atau jumlah seluruh penduduk dalam suatu negara dalam memproduksi barang dan jasa jika ada permintaan terhadap tenaga mereka, dan jika mereka mau berpartisipasi dalam aktivitas tersebut. Tenaga kerja adalah penduduk pada usia kerja yaitu antara 15 sampai dengan 64 tahun, dinyatakan dalam satuan orang.

PAD merupakan pendapatan yang berasal dari dalam daerah yang berasal dari hasil pajak daerah, hasil retribusi daerah, perolehan aba perusahaan milik daerah dan juga pendapatan lain yang sah. PAD diukur dalam satuan Rupiah. 
Analisis Pengaruh Belanja Pemerintah, Tenaga Kerja dan.......( Hidayat, Nalle)

PEMBAHASAN

Dalam menentukan metode terbaik regresi data panel, dapat dilakukan setidaknya dua macam pengujian, yakni Uji Chow yang memberi pilihan antara Common Effect Model (CEM) dan Fixed Effect Model (FEM). Hasil Uji Chow dalam penelitian ini dapat dilihat pada tabel berikut:

Tabel 3. Hasil Uji Chow

\begin{tabular}{cccc}
\hline Effects Test & Statistic & d.f. & Prob. \\
\hline Cross-section F & 257.015846 & -37187 & 0.0000 \\
\hline Cross-section Chi-square & 900.239887 & 37 & 0.0000
\end{tabular}

\section{Sumber: Data diolah}

Dari tabel 3, diketahui bahwa nilai nilai $\mathrm{p}$-value Obs*r square = 0,0000. Sehingga didapatkan bahwa p-value $0 b{ }^{*}$ r square $0,0000<0,05$ maka H0 ditolak. Maka, pada tingkat keyakinan 95\% Fixed Effect Model (FEM)lebih baik digunakan dalam penelitian ini. Untuk memperkuat hasil Uji Chow, dilakukan pengujian yang kedua yakni Uji Hausman yang memberikan pilihan antara Random Effect Model (REM) dan Fixed Effect Model (FEM). hasil Uji Hausman dalam penelitian ini dapat dilihat pada tabel berikut:

\section{Tabel 4: Hasil Uji Hausman}

\begin{tabular}{rccc}
\hline Test Summary & Chi-Sq. Statistic & Chi-Sq. d.f & Prob. \\
\hline Cross-section random & 160.434375 & 3 & 0,0000 \\
\hline
\end{tabular}

\section{Sumber: Data diolah}

Dari hasil Uji Chow didapatkan dilakukan estimasi dengan metode hasil bahwa metode estimasi yang tersebut didapatkan hasil tentang sesuai adalah fixed effect model pengaruh variabel belanja pemerintah, (FEM), begitu pula dengan Uji tenaga kerja, dan PAD terhadap Hausman. Maka analisis data panel variabel pertumbuhan ekonomi dalam penelitian ini menggunakan regional sebagai berikut :

fixed effect model (FEM). Setelah

Tabel 5. Hasil Regresi dengan Fixed Effect Model (FEM)

\begin{tabular}{lcc}
\hline Variabel & Koefisien & Prob \\
\hline Konstanta & -2858.124 & 0,5820 \\
\hline Belanja Pemerintah & $(-0.551468)$ & \\
\hline & 3.232698 & $0,0009^{*}$ \\
\hline
\end{tabular}


Analisis Pengaruh Belanja Pemerintah, Tenaga Kerja dan.......( Hidayat, Nalle)

\begin{tabular}{lcc}
\hline Tenaga Kerja & 0.04966 & $0,0000 *$ \\
\hline & $(4.961007)$ & $0,0000^{*}$ \\
\hline PAD & 2.741013 & \\
\hline $\mathrm{R}^{2}$ & $(17.40857)$ & \\
F-statistik Prob(F-statistik) & 0.9975 & \\
& 1865.473 & \\
\hline
\end{tabular}

*signifikan pada $\alpha=1 \%$,

$* *$ signifikan pada $\alpha=5 \%$,

$* * *$ signifikan pada $\alpha=10 \%$

Sumber: Data primer (diolah), 2017

Dari hasil estimasi di atas dapat

dibentuk model persamaan

sebagai berikut:

PDRB = -2858.124 + 3.232698 BP + 0.04966 TK + 2.741013 PAD

Dari persamaan di atas, diketahui bahwa seluruh variabel independen, yakni belanja pemerintah, tenaga kerja, dan pendapatan asli daerah (PAD) berpengaruh positif dan signifikan terhadap pertumbuhan ekonomi regional. Pada kondisi otonom, saat variabel $\mathrm{BP}$, TK, dan PAD bernilai nol maka pertumbuhan ekonomi regional Provinsi Jawa Timur adalah sebesar -2858.124 juta Rupiah.

Diketahui $\mathrm{R}^{2}$ dalam model ini adalah sebesar 0,9975, yang artinya sebesar 99,75\% variabel independen yang digunakan mampu menjelaskan model, sedangkan $0,25 \%$ sisanya dijelaskan oleh variabel di luar model. Sedangkan

nilai F-statistik dalam model ini adalah sebesar 1865.473 dengan probabilitas sebesar 0,0000. Dengan probabilitas sebesar 0,0000 (lebih kecil dari $\alpha$ 0,05) maka dapat disimpulkan bahwa secara simultan variabel independen belanja pemerintah, tenaga kerja, dan PAD mempunyai pengaruh signifikan terhadap variabel dependen pertumbuhan ekonomi regional.

Dalam uji signifikansi parsial, diketahui bahwa variabel belanja pemerintah (BP) memiliki pengaruh positif dan signifikan, dengan koefisien sebesar 3.232698. Maka artinya kenaikan satu unit belanja pemerintah akan menaikkan pertumbuhan ekonomi regional sebesar 3.232698 unit, cateris paribus.

Variabel tenaga kerja (TK) memiliki pengaruh positif dan signifikan terhadap pertumbuhan ekonomi regional, dengan koefisien 
sebesar 0.04966. Artinya, kenaikan satu orang tenaga kerja akan menaikkan pertumbuhan ekonomi regional rata-rata sebesar 0.04966 unit, cateris paribus..

Variabel Pendapatan Asli Daerah (PAD) juga memiliki pengaruh positif dan signifikan terhadap pertumbuhan eonomi regional, dengan koefisien sebesar 2.741013. Artinya, kenaikan satu unit PAD akan menaikkan pertumbuhan ekonomi regional ratarata sebesar 2.741013, cateris paribus.

\section{KESIMPULAN}

Berdasarkan hasil analisi data panel sebelumnya, maka didapatkan kesimpulan sebagai berikut: 1) Belanja pemerintah berpengaruh positif dan signifikan terhadap pertumbuhan ekonomi regional di Jawa Timur. Besarnya alokasi belanja yang salah satunya digunakan untuk pembentukan modal menjadi penyokong pertumbuhan ekonomi di Jawa Timur.Selain itu belanja pemerintah barang dan jasa menjadi pemasukan bagi rumah tangga dan mengahsilkan multiplier effect dengan meningkatkan daya beli masyarakat, 2) Tenaga kerja berpengaruh positif dan signifikan terhadap pertumbuhan ekonomi regional di Jawa Timur. Hal ini sesuai dengan teori, Todaro (2000) bahwa pertumbuhan penduduk dan pertumbuhan Angkatan Kerja (AK) secara tradisional dianggap sebagai salah satu faktor positif yang memacu pertumbuhan ekonomi. Jumlah tenaga kerja yang lebih besar berarti akan menambah tingkat produksi, sedangkan pertumbuhan penduduk yang lebih besar berarti ukuran pasar domestiknya lebih besar, 3) Pendapatan Asli Daerah (PAD) berpengaruh positif dan signifikan terhadap pertumbuhan ekonomi di Jawa Timur, karena PAD merupakan indikator potensi yang telah digali di suatu wilayah. Maka semakin tinggi PAD yang dapat dipungut, penerimaan pemerintah daerah juga semakin tinggi. Begitu pula dengan tingkat kemandirian daerahnya. Ini juga memperlihatkan bahwa penarikan pajak dan retribusi daerah yang dilakukan pemerintah daerah mampu mendorong pertumbuhan ekonomi daerah, misalnya melalui pembangunan infrastruktur.

\section{SARAN}

Berdasarkan kesimpulan yang telah dirinci diatas, saran-saran yang dapat diberikan antara lain sebagai 
Analisis Pengaruh Belanja Pemerintah, Tenaga Kerja dan.......( Hidayat, Nalle)

berikut: 1) Pengeluaran pemerintah dialokasikan dengan efisien sesuai dengan kebutuhan masing-masing kabupaten/kota. Penambahan alokasi jumlah belanja modal diharapkan dapat lebih meningkatkan pertumbuhan ekonomi dalam jangka panjang, 2) Pemerintah daerah perlu meningkatkan kualitas angkatan kerja yang tumbuh setiap tahunnya mengingat tenaga kerja adalah sebagai salah satu sumber daya lokal yang tidak hanya menjadi objek pembangunna, tetapi juga subjek pembangunan itu sendiri. Upaya tersebut dapat dilakukan dengan pembekalan pendidikan dan pelatihan sehingga mampu bersaing di pasar kerja dan juga sebagai upaya menarik investor untuk datang ke daerah yang memiliki sumber daya manusia yang berkompeten sehingga mau menanamkan modalnya guna kepentingan pembangunan daerah, 3) Perlu adanya upaya pemerataan ekonomi di setiap kabupaten dan kota di Jawa Timur guna menekan ketimpangan antar daerah, misalnya yang bersumber dari PAd karena setiap daerah memiliki keragaman masing-masing, sehingga potensi yang dapat digali tidaklah sama. Dan hal menentukan besarnya target PAD suatu daerah, juga harus dilakukan dengan teliti dan tepat, sehingga tidak membebani masyarakat dan menjadi disinsentif ekonomi.

\section{DAFTAR PUSTAKA}

Anonim. 2014. Dampak Belanja Pemerintah terhadap Pengangguran dan kemiskinan di Indonesia. Kementerian Keuangan RI. Diakses dari http://www.kemenkeu.go.id/en/no $\underline{\text { de/44735 }}$

Hirawan, Susiyati B. 1987. Keuangan Daerah di Indonesia. Jakarta: LPFE UI.

Kaho, Josef Riwu. 1998. Prospek Otonomi Daerah di Negara Republik Indonesia. Jakarta: Raja Grafindo Perkasa.

Kuncoro, Mudrajat. 2004. Otonomi dan Pembangunan Daerah. Jakarta: Erlangga.

Mankiw, Gregory. 2006. Pengantar Ekonomi Makro Edisi Ketiga. Jakarta: Salemba Empat.

Mardiasmo. 1997. Perpajakan. Yogyakarta: Andi.

Mardiasmo. 2002. Akuntansi Sektor Publik. Yogyakarta: Andi.

Suparmoko. 1997. Ekonomi Sumber Daya Alam dan lingkungan. Yogyakarta: BPFE.

Suparmoko. 2002. Ekonomi Publik Untuk Keuangan dan Pembangunan Daerah. Jakarta: 
Analisis Pengaruh Belanja Pemerintah, Tenaga Kerja dan.......( Hidayat, Nalle)

ANDI.

Sukirno, Sadono. 1994. Pengantar

Teori Makro Ekonomi Edisi 2. Jakarta: Raja Grafindo Persada.

Sutrisno. 1984. Dasar-dasar Ilmu

Keuangan Negara. Yogyakarta: BPFE.
Todaro, Michael P. 2000.

Pembangunan Ekonomi di Dunia Ketiga Edisi Ketujuh (Terjemahan Haris Munandar). Jakarta: Erlangga.

Todaro, Michael P. dan Smith, Stephen C. 2006. Pembangunan Ekonomi. Jakarta: Erlangga. 